International Journal of Business and Management Review

Vol.8, No.4, pp.78-100, July 2020

Published by ECRTD-UK

Print ISSN: 2052-6393(Print), Online ISSN: 2052-6407(Online)

\title{
FINANCIAL RISK AND FINANCIAL PERFORMANCE OF DEPOSIT MONEY BANKS LISTED IN NIGERIA
}

\author{
Olaoye, Samuel Adebayo (Ph.D) \\ Lecturer, Department of Accounting, Babcock University, Ilishan-Remo, Ogun State \\ Ogbebor, Peter Ifeanyi (Ph.D) \\ Lecturer, Department of Finance, Babcock University, Ilishan-Remo, Ogun State \\ Okusami, Yusuf Abiodun \\ Masters Student, Department of Finance, Babcock University, Ilishan-Remo, Ogun State
}

\begin{abstract}
This study examined the effect of financial risks on performance of Deposit Money Banks DMBs) using the identified explanatory variables of financial risks, viz: Credit risks, Insolvency risks, Liquidity risks and Market risks covering a period of 12 years (2007-2018). The methodology of the study makes use of ex-post facto research design. While the population of the study were nineteen deposit money banks, the study sample comprised ten (10) DMBs. The panel regression models estimated using Unobserved Effects Model (UEM), while the result of the Hausman test indicated between fixed effect model and random effect model at $5 \%$ inference. The study findings showed that Credit Risk was negative and statistically significant to deposit money banks' performance $[\beta=-13.0495 ;$ Pval $=0.013]$. The result also shows that Liquidity Risk is inversely and insignificantly related to banks' profitability $[\beta=-0.156 ;$ Pval $=0.6703]$ and Insolvency Risk (INSRK) have negative signs that are statistically insignificant to banks profitability $[\beta=-0.016 ;$ Pval $=0.745]$. Market Risk has insignificant and positive effect on Profitability (NPBIT) $[\beta=0.038 ;$ Pval $=0.5720]$ at 0.05 level. Also, Credit Risk $(C R)$ was found to be negative and statistically significant at Economic Value Added [ $\beta=-7.0789 ;$ Pval $=0.006]$. On the contrary, the result also shows that Liquidity Risk $(L I Q R)[\beta=0.0264 ;$ Pval $=0.961]$ and Market Risk $[\beta=0.0369 ;$ Pval $=0.747]$ have positive signs that are statistically insignificant to Economic Value Added. On its part, Credit Risk $(C R)$ established a negative and significant effect on Return on Assets [ $\beta=-0.9647 ;$ Pval $=0.0421]$. Liquidity Risk [ $\beta=-0.0018 ;$ Pval $=0.8471]$ and Insolvency Risk [ $\beta=0.0008 ;$ Pval $=0.7719]$ have negative and positive signs that are statistically insignificant to Return on Assets. In relation to the findings of the study, the study recommended amongst others that it is fundamental for DMBs in Nigeria to practice scientific credit risk management, improve their efficacy in credit analysis and loan management to secure as much as possible their assets, and minimize the high incidence of non-performing loans and their negative effects on financial performance.
\end{abstract}

KEYWORD: credit risk, economic value added, financial risk, insolvency risk, market risk, profitability. 
International Journal of Business and Management Review

Vol.8, No.4, pp.78-100, July 2020

Published by ECRTD-UK

Print ISSN: 2052-6393(Print), Online ISSN: 2052-6407(Online)

\section{INTRODUCTION}

The financial performance of Deposit Money Banks (DMBs) plays a pivotal role in the growth and development of a nation. This is because they have to manage huge volume of transactions. Accordingly, investors, capital market participants and other stakeholders need to understand the financial performance of DMBs: granting credit facilities and other financial services. Naturally, the ability of DMBs to meet their existing financial obligations, operating efficiency and their financial performances are associated with some financial risks. Some financial performance evaluating tools of profitability, return on assets and economic value added are considered appropriate for Deposit Money Banks for the stakeholders' interest (Nataraja, Nataraja \& Ganesh, 2018). According to Muriithi and Muigai (2017) financial risk threatens the financial stability and performance of financial sector. Financial risk is defined as all risks which would generate volatility in a bank's reserves, expenses and the value of their business. If financial risk is not addressed systematically it can result into inconsistent performance and earnings for the stakeholders and impact banks' revenues and net worth sometimes with disastrous systemic consequences as demonstrated by Hess, (2011).

Pinto, Hawaldar, Rahiman, Rajesha and Sarea (2017) stressed that the financial performance of DMBs are essentially required in the economic policy formulation and a tool in the analysis of the outcomes of a firm's policies, performance, efficiency and effectiveness in monetary terms of the country where they operate. Basically, financial performance evaluation is a subjective measure to assess firm's usage of assets from its primary mode of business and generation of revenues. Some performance measures of DMBs activities includes net operating income (NPI), earnings before interest and taxes (EBIT), profit after taxes (PAT) and net asset value (NAV). Performance also includes an evaluation of the manner the banks are efficiently using their assets and other resources to generate revenues, which affect firm's overall financial condition for a given period, and can be used to compare one sector with the other. Finance and its function play a very significant role in determining the profitability and stability of the business (Hawaldar, Rajesha, Lokesha \& Kumar, 2017; Pinto et al. 2017).

From the Nigerian DMBs perspective, there are studies on banking sectors and associated risks. For example, the studies by (Achumba, Ighomereho \& Akpr-Robaro, 2013; Kanu \& Isu, 2016; Kanu \& Okorafor, 2013; Nwankwo, 2013; Uchenna \& Agbo, 2013; Ugwu, 2012) illustrate the effects of financial risks on the financial performance in their studies. Specifically, Ugwu (2012) opined that most DMBs operating in Nigeria in an effort to perform, got involved in multiple risks such as credit risk, liquidity risk and underfunding which made some DMBs in Nigeria to operate with capitalization of less than $\$ 10$ million. Even the largest bank in Nigeria has a capital base of about US \$240 million compared to US \$526 million for the smallest bank in Malaysia. In spite of these studies, the performance and sustainability of DMBs profitability continue to nosedive to a point that the Nigerian DMBs reported losses recently at an alarming rate (Kanu \& Isu, 2016). Problems of inconsistencies and financial risks and the level of non-performing loans in DMBs in Nigeria are unprecedented. Unfortunately, bank managers seem not bothered so long as their suboptimality syndrome and personal interests are met, as these managers consistently engage in shady ventures at the expense of the shareholders, and possible adverse effects on the banks (Enofe, Ekpule, Onobun \& Onyekweni, 2015). 
From the Nigerian perspective, the problem of financial risks and the financial performance of DMBs is quite complex and unresolved, ranging from the problems of poor and inadequate profitability, problem of unsustainability, inability to create economic value for the shareholders' and meagre returns on assets due to poor utilization of the banks' available assets (Kanu \& Isu, 2016). Lending credence to this, Olalere, Aminu, Yusoff and Shamsuddin (2018) opined that financial risks in DMBs is actually somewhat challenging and different from other risks facing banks, as it is not only systemic in nature, but asymmetric, reducing banks' financial and nonfinancial performances leading to huge losses, loss of confidence of both investors and depositors alike. DMBs are ridden with problems of huge nonperforming loans, in-house fraudulent activities and high level of disposition of unprofessionalism among the managers, coupled with inadequate board monitoring in line with best corporate governance among the executive and non-executive directors (Oyerogba, Ogungbade \& Idode, 2016). This study in consideration of these problems, and in an effort to contribute and extend the frontiers of knowledge on how this problem can be ameliorated significantly proceeds to proffer solutions to the problems of financial performance of DMBs by investigating the effect of financial risks on financial performance by using the identified explanatory variables of financial risks such as credit risks, insolvency risk, liquidity risks and market risks.

\section{LITERATURE REVIEW}

The concept of financial performance is an appraisal measure of the level of organization's policies in yielding the desired financial objective in monetary terms. Adina (2015) opined that financial performance is a measure of a company and the managers of such establishment's performance and overall operational efficiency and its ability to optimally utilize the resources available to it. The performance of a DMBs could be used as yard stick to measure another DMBs in the same category in terms of size, capitalization and staff strength who operate in the same industry (Abdolazim, 2014). Basically, the financial performance of a DMBs could be a reflection of the trends in the banks return on assets, profitability, economic value added, return on equity, liquidity, solvency, riskiness of the bank and many others like how fast it concludes a loan facility request and ability to manage the loan facilities, the low level of non-performing loans (Arroyave, 2018; Faith \& Agnes, 2015; El-Ansary, 2019; Fan \& Yijun, 2014). The study by Makokha, Mukanzi and Maniagi (2016) and that of Shrivastave, Kumar and Kumar (2018) posited that financial performance is the measure of how well a firm uses its assets to generate revenues. This definition is used as a general measure of a firm's overall financial soundness over a given period of time, and can be used to compare similar firms in the same industry and across industry in aggregate. Financial performance measures are directed at reviewing the efficient and effective utilization of resources available to a firm aiming at maximizing returns of an organization as presented in financial statements. Similarly, Kariuki and Peddy (2017) opined that financial performance of a business enables managers and decision-makers to measure the results of business strategies and activities in an objective and unbiased monetary terms. It, therefore, facilitates measurement of a firm's overall financial health over a given period of time, and can be used to compare similar firms across the same industry. 
International Journal of Business and Management Review

Vol.8, No.4, pp.78-100, July 2020

Published by ECRTD-UK

Print ISSN: 2052-6393(Print), Online ISSN: 2052-6407(Online)

Financial risk is any type of risk associated with financing and investment. In the case of banks, it is always debilitating and often times, beyond financial losses but also a reputational issue. Often, it is understood to include only downside risk. Ideally, the concept of financial risk is the risk associated with the day to day activities of DMBs. Presumably, one of the oldest and most challenging type of risks a DMBs may face in the process of carrying out its legitimate operational duties (Mostafa, Mahmoud, Jalal \& Elahe, 2016). Financial risk events stem from varied causes, including defaulting in loans repayment that results in nonperforming loans (NPL) or credit risk (CR), Liquidity risk, (LIQR), Insolvency risk (INSRK), Market risk (MKTR). Others are Interest rate risk, Currency risk, and Business risk that may arise in a financial transaction.

The study is anchored on Uncertainty Theory. Uncertainty theory was developed by Charles Berger and Richard Calabress in February 1975. The uncertainty theory is devoted to the handling of incomplete information. To a large extent, it is comparable to probability theory because it is based on set-functions. It differs from the latter by the use of a pair of dual set functions (possibility and necessity measures) instead of only one. Besides, it is not additive and makes sense on ordinal structures. According to Didie and Henri (2011) possibility theory lies at the crossroads between fuzzy sets, probability and non-monotonic reasoning. Possibility theory can be cast either in an ordinal FR in a numerical setting. Qualitative possibility theory is closely related to belief revision theory, and common-sense reasoning with exception-tainted knowledge in Artificial Intelligence. Quantitative possibility theory is the simplest framework for statistical reasoning with imprecise probabilities. In supporting this theory, Andrew, Mustafa and Violet (2013) posited that the importance of possibility theory especially in the perception of probability and statistical intuition in economic sense cannot be overlooked. Theory of possibility like probability is applied in the study and analysis of risks, ranking alternatives, decision making and even in investment among other interesting applications.

Contrary to the proponents of the theory, Mohamed and McCowan (2011) found flaws in the theory. The authors explained that forecasting FR making a suitable decision may not necessarily be a way of overcoming the challenges posed by such options requiring modeling of such investment decisions under uncertainty through the application of possibility theory. Financial risk and every other risk is interlinked with uncertainties. Financial performance of the Deposit Money banks hangs on the balance of insolvency and uncertainties and this could create unstable environment for present and potential investors and bank customers in Nigeria. Consequently, this theory is considered appropriate and suitable for this study.

In conducting a study on risk management practices on Jordanian Islamic banks' performance, Yousfi (2014) used a selected credit risk (debt and risk), Financial risk (efficiency, income and cost ) liquidity risk (liquidity, capital) and market risks (inflation, interest rates and financial crisis) to shows influence on return (ROA) on assets and return on equity (ROE) for the period of 15 years from 1998 to 2012. The pooled least square method with fixed effect was used to analyze and test the study hypotheses. The results revealed that liquidity, credit and financial risk management practices have a negative and significant statistical impact on Islamic banks' 
International Journal of Business and Management Review

Vol.8, No.4, pp.78-100, July 2020

Published by ECRTD-UK

Print ISSN: 2052-6393(Print), Online ISSN: 2052-6407(Online)

performance. These banks failed at the same time in managing these risks. Also, market risk management practices had a positive and significant statistical impact on banks' performance which, means that these banks don't suffer neither from the financial risk during the study period nor from managing this type of risk. Similarly, Faris (2015) investigated the impact of financial and business risk on performance in ten industrial sector of Sultanate of Oman. The population was 47 firms from the period 5 years (2009 to 2013), using descriptive statistics. The results indicated that there was a statistical significant impact of earnings growth of business risk on performance at significant level 5\% and current ratio and financial leverage at financial risk on performance at significant level $1 \%$. The multiple regressions showed there was a significant impact of all business and financial risk variables on performance at significant level $10 \%$. The stepwise regression also showed that the financial risk related to current ratio variable between all independent variables is a significant impact on performance at significant level 1\%. More so, Saarman (2017) examined the development of financial performance in the 21 st century using Svenska Handelsbanken AB as a case study. The element of risk was added to the study with the objective to identify correlations between performance and risk. The research was conducted by observing the company's statement of financial position and income statements in order to formulate the calculations for performance and risk ratios. The data was collected and analyzed for the period of 17 years (2000-2016). This supported the element of choosing the financial crisis as an important event during the analysis. The results showed that Handelsbanken had a good financial position and that its strict risk management had worked effectively. The study also found that the financial crisis had no significant effect on the performance and risk development of Handelsbanken. Nurlida (2017) conducted an investigation on the risk and performance of one conventional bank in Malaysia. Their study employed on credit risk ratio, liquidity ratio, financial risk ratio, and performance indicators of return on asset ratio, return on equity ratio, net interest margin as were used for a period of 5 years (2011-2015). Panel data analysis found that risk positively affected performance. Ahmad (2018) carried out a study to examine the impact of risk management practices on the profitability of Jordanian DMBs, using a sample of 13 Jordanian DMBs during the period (2010-2015). Data regarding variables were collected from the annual financial statements of the study. Return on assets represented the profitability of banks, while risks management practices consisted of liquidity, operational, credit and market risks. The study used two ratios to symbolize each type of risk. The ordinary least square method (Fixed effect and Random effect) was used to test the hypothesis. The study revealed that risk management practices as a whole explain a significant part of the variation in banks' profitability. The results also showed that, only financial risk management practices significantly affected the profitability, while liquidity, credit and market risks have insignificant effects. The implications of the results indicated that Jordanian DMBs (JCB) have successfully managed liquidity, credit, operating income and market risks during the study period, but at the same time failed to manage financial risk represented in overheads.

Prior to the study in Africa, Muriithi and Waweru (2017) study explored the effect of financial risk on financial performance of DMBs in Kenya. The qualitative research design and ordered logistic model were employed, using listed DMBs in Kenya for a period of 5 years (2012-2016), where data were sourced. The conclusion of the study was that there exists an inverse relationship between financial risk and financial performance. The study also found that bank size moderates 
International Journal of Business and Management Review

Vol.8, No.4, pp.78-100, July 2020

Published by ECRTD-UK

Print ISSN: 2052-6393(Print), Online ISSN: 2052-6407(Online)

the effect of internal and external fraud on financial performance of DMBs in Kenya by shrinking the performance. Bank size moderated the effect execution, delivery and process management on financial performance of DMBs in Kenya by enhancing it. DMBs' management should adhere to the guidelines and procedures provided by the Central bank of Kenya on Financial risk management.

Performance Jamal, Mohamed and Ali (2014) conducted a study on the impact of financial risks on the firms' performance. The study was based on an arm chair analyses. The study used descriptive and simple regression to analyze data sourced from the selected companies, for a period of 4 years (2000-2013). The researchers concluded that financial risks had a significant impact on the performance of firms selected for the study. the study revealed that operations in form of asset acquisitions and maintenance of existing assets as globalization opens up the firm to outside competition, which in the long-run effects its performance. Also, that financial and credit risk affects lending and borrowing by financial firms. Finally that foreign exchange risks make firms incur unpredictable losses thus affecting their performance. Muriithi (2016) investigated the effect of financial risk on financial performance of DMBs in Kenya. The quantitative research design was adopted in the study, using 43 DMBs licensed by CBK as at December 2014. Time Series Cross Sectional unbalanced secondary panel data was used for the analysis. The data was obtained from published financial statements of accounts of all 43 DMBs in Kenya, CBK, and the Banking survey publications for ten years from 2005 to 2014. The study used financial ratio analysis and panel data techniques of random effects, fixed effects estimation and generalized method of moments (GMM) to purge time-invariant unobserved firm specific effects and to mitigate potential endogeneity problems. The findings of the study indicated that credit, market, liquidity and operational risks have significant negative effect on return on equity. The component of financial risk that had the most impact on financial performance was cost to income ratio. The conclusion of the study was that there existed inverse relationship between financial risk and financial performance of Kenyan DMBs. Hence the DMBs together with the bank supervisors should make a trade-off between financial risk and financial performance.

In the case Nigeria, Olalere and Wan (2013) investigated the effect of credit risk on profitability of DMBs in Nigeria. Specifically, the study sought to determine the significant effects of credit risk and its indicators; and the relationship between the indicators influence on the profitability of banks. A total 8 DMBs were selected for the study for a period of 4 years (2011-2014). A panel data analysis was employed for the study to provide the analytical model while validity and reliability tests were carried out. The study found that there was a negative and significant relationship between non-performing loan ratio and profitability; negative and insignificant relationship between debts to total assets ratio and profitability, and a positive and insignificant relationship between debts to equity ratio and profitability of banks during the period of study. In general, the results proposed that banks needs to refocus on the effective management of their inherent risks which often affect their profitability and financial viability. Therefore, the study concluded that credit risk impacted on profitability of DMBs in Nigeria. The study by Soyemi, Ogunleye and Ashogbon (2014) on the effect of risk management practices on financial performance among DMBs in Nigeria used secondary data gathered from the sampled listed banks' Financial Statement and Accounts. The study employed variables such as non-performing loans, 
International Journal of Business and Management Review

Vol.8, No.4, pp.78-100, July 2020

Published by ECRTD-UK

Print ISSN: 2052-6393(Print), Online ISSN: 2052-6407(Online)

liquidity, operating cost and capital adequacy to measure risk management practices and return on assets and return on equity to proxy the financial performance. The cross sectional data obtained were analysed using descriptive statistics and multiple regression to depict patterns. Thereafter a robust standard error, OLS regression was used to estimate any significant influence between the banks' risk management practices and their financial performance.

Osadahun (2014) examined critically the effect of operational risks and financial risk management techniques on Nigerian banks. The research employed a qualitative study in the form of administering interviews with the executives from chosen banks of Nigeria. It was found that the most common fraud within the bank operations in Nigeria were utilization of trickery, disobedience of standards, bank cheating, official, outside trade, household operations, compromise, currency business sector and treasury, hazard possessions, data engineering, budgetary control, clearing, trust exchange, teller operations. To improve the service delivery of the system innovative based technology should be incorporated into the governing system. Nigeria's banking sector is gradually completing the implementation of Basel III and will allocate adequate financial risk capital, however Nigeria has not established a uniform financial risk loss database for its DMBs. This explains that the Nigerian banking regulations requires a re-think and applied accordingly on a wider scale by the financial institutions. Epetimehin and Obafemi (2015) carried out a study to investigate effect of financial risk management on the financial development and economic value added and growth of some financial institutions in Nigeria. The study used a survey research design and received validated questionnaires from 150 respondents from different financial institutions, such as banks, insurance, stockbrokers and microfinance companies. Analysis of Variance (ANOVA) was used to test the hypothesis and response of respondents was analyzed through the use of Statistical Package for Social Science (SPSS, 20). The result showed that financial risk management had a significant positive effect on economic value added and on financial development and growth in the financial sector.

\section{METHODOLOGY}

This study used ex-post facto research design. Panel data was used due to the nature of the stated model variables, for multiple regression analysis, since time and cross-sectional effects of the data were analysed in the study. The researcher extracted data from annual audited reports and financial statements of the DMBs selected for the study. The population of the study consisted of all the listed 19 DMBs on the floor of the Nigeria Stock Exchange (NSE) as at 31 December, 2018. A convenience random sampling technique was adopted for the study.

The sample size of the study was determined using the Krejcie and Morgan (1970) sample size formula. The number of listed DMBs in the study were Nineteen (19) and the period covered twelve years (2007-2018), as such the elements of the sampling unit is 228 (12 years *19 companies). Using the Krejcie and Morgan (1970) sample size formula:

$S=\frac{X^{2} * N * P(1-P)}{D^{2}(N-1)+X^{2} * P(1-P)}$

Where $\mathrm{S}=$ Sample size; 
$\mathrm{X}^{2}=$ table value of chi-square @ D.F =1 for desired confidence level;

$\mathrm{N}=$ Population size;

$\mathrm{P}=$ Population proportion (assumed to be 0.50 );

$\mathrm{D}=$ degree of accuracy (expressed as a proportion $=0.05$ ).

With $N=228 ; X^{2}($ at $\propto=0.05)=3.84 ; P=0.50$

The sample size for this study will be:

$S=\frac{3.84 * 228 * 0.25}{\left(0.05^{2} * 227\right)+(3.84 \times 0.25)}$

$S=\frac{218.88}{(0.5675)+(0.96)}$

$S=\frac{218.88}{1.5275}$

$S=143.30$ approx. 143 observations

From the sample size calculation carried out, it revealed that the 143 observations were calculated. However, due to non-availability data, 120 observations reflecting $84 \%$ of the calculated observation was used for the study $(143 * .84)=120$ observations. Accordingly, 10 DMBs for a period of 12 years were used for the study.

\section{Model Specification}

$\mathrm{Y}=f(\mathrm{XZ})$.

$\mathrm{Y}_{\mathrm{it}}=\beta_{0}+\beta_{1} \mathrm{XZ}_{\mathrm{it}}+\varepsilon_{\mathrm{it}}$ Equation 1

Where

$\mathrm{Y}=$ dependent variable: Financial Performance (FP)

$\mathrm{X}=$ independent variable: Financial risk (FR)

$\mathrm{Z}=$ Controlling Variables

$\beta_{0}=$ regression intercept which is constant

While $\beta_{1}, \beta_{2}, \beta_{3}, \beta_{4}, \beta_{5}=$ the coefficient of the explanatory variables

$\varepsilon$ is the error term of the model

$i=$ cross-sectional variable

$t=$ time series variable

Functional Relationship

NPMR $=f(\mathrm{CR}$, LIQR, INSRK, MKTR $) \quad$ F 1

$\mathrm{EVA}=f(\mathrm{CR}, \mathrm{LIQR}, \mathrm{INSRK}, \mathrm{MKTR}) \quad \mathrm{F} 2$

$\mathrm{ROA}=f(\mathrm{CR}, \mathrm{LIQR}, \mathrm{INSRK}, \mathrm{MKTR}) \quad \mathrm{F} 3$

NPMR $=f(C R$, LIQR, INSRK, MKTR, FRMSIZ $) \quad$ F 4

$\mathrm{EVA}=f(\mathrm{CR}, \mathrm{LIQR}$, INSRK, MKTR, FRMSIZ) $\quad$ F 5

ROA $=f(\mathrm{CR}$, LIQR, INSRK, MKTR, FRMSIZ $) \quad$ F 6

Models Specification

$N P M R_{i t}=\beta_{0}+\beta_{1} C R_{i t}+\beta_{2} L I Q R_{i t}+\beta_{3} I N S R K_{i t}+\beta_{4} M K T R_{i t}+\varepsilon_{i t}$

Model

1 
Vol.8, No.4, pp.78-100, July 2020

Published by ECRTD-UK

Print ISSN: 2052-6393(Print), Online ISSN: 2052-6407(Online)

$$
\begin{aligned}
& E V A_{i t}=\beta_{0}+\beta_{1} C R_{i t}+\beta_{2} L I Q R_{i t}+\beta_{3} I N S R K_{i t}+\beta_{4} M K T R_{i t}+\varepsilon_{i t} \\
& \text { Model } 2 \\
& R O A_{i t}=\beta_{0}+\beta_{1} C R_{i t}+\beta_{2} L I Q R_{i t}+\beta_{3} I N S R K_{i t}+\beta_{4} M K T R_{i t}+\varepsilon_{i t} \\
& \text { Model } 3 \\
& N P M R_{i t}=\beta_{0}+\beta_{1} C R_{i t}+\beta_{2} L I Q R_{i t}+\beta_{3} I N S R K_{i t}+\beta_{4} M K T R_{i t}+\beta_{5} F_{R M S I Z}+\varepsilon_{i t} \\
& 4 \\
& E V A_{i t}=\beta_{0}+\beta_{1} C R_{i t}+\beta_{2} L_{I Q R}+\beta_{i t}{ }_{3} I N S R K_{i t}+\beta_{4} M K T R_{i t}+\beta_{5} F R M S I Z_{i t}+\varepsilon_{i t} \\
& R O A_{i t}=\beta_{0}+\beta_{1} C R_{i t}+\beta_{2} L_{I Q R}+\beta_{i t} I N S R K_{i t}+\beta_{4} M K T R_{i t}+\beta_{5} F_{R M S I Z}+\varepsilon_{i t}
\end{aligned}
$$

\section{Main Model}

Financial performance $(\mathrm{FP})=\mathrm{f}(\mathrm{CR}, \mathrm{LIQR}, \mathrm{INSRK}, \mathrm{MKTR}, \mathrm{FRMSIZ}) \quad$ Main Model $F P_{i t}==\beta_{0}+\beta_{1} C R_{i t}+\beta_{2} L I Q R_{i t}+\beta_{3} I N S R K_{i t}+\beta_{4} M K T R_{i t}+\beta_{5} F R M S I Z_{i t}+\varepsilon_{i t}$

Where

NPMR: Profitability (Net profit margin ratio)

EVA: Economic value Added

CR: Credit Risk

LIQR: Liquidity risk

INSRK: Insolvency risk

MKTR: Market Risk

FRMSIZ: Firm Size

FP $=$ Financial Performance

The purpose of the models was to determine whether there were relationships between financial risk and financial performance and their proxies. The variables were selected on the basis of their relevance to the model, and because of their importance in depicting shareholders and other stakeholders' confidence. The stochastic term was included in the model to accommodate the effect of other measures of financial risk proxies and financial performance not included in the model.

\section{Measurement and explanation of identified variables}

Financial risk (FR) attributes were credit risk (CR), Liquidity risk (LIQR) and Insolvency risk (INSRK) in this study, while profitability (NPMR), economic value added (EVA) and return on assets (ROA) were considered to measure the dependent variable. 
Vol.8, No.4, pp.78-100, July 2020

Published by ECRTD-UK

Print ISSN: 2052-6393(Print), Online ISSN: 2052-6407(Online)

\begin{tabular}{|c|c|c|c|c|}
\hline Variables & Indicator & Measurement & Source & $\begin{array}{l}\text { Study } \\
\text { Replicate }\end{array}$ \\
\hline Profitability & NPMR & $\frac{\text { Net Profit before Interest \&Tax }}{\text { Gross Earnings }}$ & $\begin{array}{l}\text { Annual } \\
\text { Financial report } \\
\text { of selected } \\
\text { banks for } \\
\text { several years }\end{array}$ & $\begin{array}{l}\text { adopts } \\
\text { Iacobelli } \\
(2018)\end{array}$ \\
\hline $\begin{array}{l}\text { Economic } \\
\text { Value Added }\end{array}$ & EVA & $\begin{array}{l}\text { Net operating profit after tax - } \\
\text { (Capital Invested x Weighted } \\
\text { Average Cost of Capital) }\end{array}$ & $\begin{array}{l}\text { Annual } \\
\text { Financial report } \\
\text { of selected } \\
\text { banks for } \\
\text { several years } \\
\end{array}$ & $\begin{array}{l}\text { Bhasin } \\
(2017)\end{array}$ \\
\hline $\begin{array}{l}\text { Return on } \\
\text { Assets }\end{array}$ & ROA & $\frac{\text { Net Profit before Interest and Tax }}{\text { Total Assets }}$ & $\begin{array}{l}\text { Annual } \\
\text { Financial report } \\
\text { of selected } \\
\text { banks for } \\
\text { several years }\end{array}$ & $\begin{array}{l}\text { Idekwulim } \\
(2014) \text { and } \\
\text { Biswas } \\
(2016)\end{array}$ \\
\hline Credit Risk: & CR & $\frac{\text { Bad \& doubtful loan provisions }}{\text { Total Loans }} \times 100$ & $\begin{array}{l}\text { Annual } \\
\text { Financial report } \\
\text { of selected } \\
\text { banks for } \\
\text { several years }\end{array}$ & $\begin{array}{l}\text { Gadzo, } \\
\text { Kportorgbi } \\
\text { and Gatsi, } \\
2019\end{array}$ \\
\hline Liquidity risk & LR & $\frac{\text { Short }- \text { term Security }}{\text { Total Deposit }}$ & $\begin{array}{l}\text { Annual } \\
\text { Financial report } \\
\text { of selected } \\
\text { banks for } \\
\text { several years } \\
\end{array}$ & $\begin{array}{l}\text { Jilkoya and } \\
\text { Stranska } \\
(2017)\end{array}$ \\
\hline $\begin{array}{l}\text { Insolvency } \\
\text { risk }\end{array}$ & IR & $\frac{\text { Operating Expenses }}{\text { Net Operating Income }}$ & $\begin{array}{l}\text { Annual } \\
\text { Financial report } \\
\text { of selected } \\
\text { banks for } \\
\text { several years } \\
\end{array}$ & $\begin{array}{l}\text { Olalere et al. } \\
(2018)\end{array}$ \\
\hline Market risk & MR & $\begin{array}{l}\mathrm{VARx}=\mathrm{Vx}(\mathrm{dv} / \mathrm{dp}) \Delta \mathrm{Pt} \\
\mathrm{dv} / \mathrm{dP}=\text { price movement per Naira } \\
\text { market value. } \\
\mathrm{Vx}=\text { Market Value of Portfolio } \mathrm{x} \\
\mathrm{VAR}=\text { the Value-at-Risk }\end{array}$ & $\begin{array}{l}\text { Annual } \\
\text { Financial report } \\
\text { of selected } \\
\text { banks for } \\
\text { several years }\end{array}$ & $\begin{array}{l}\text { Al-Janabi et } \\
\text { al., (2019) }\end{array}$ \\
\hline Firm Size & FRMSIZ & Log of Total Assets & $\begin{array}{l}\text { Annual } \\
\text { Financial report } \\
\text { of selected } \\
\text { banks for } \\
\text { several years } \\
\end{array}$ & $\begin{array}{l}\text { Eliwa } \\
(2015)\end{array}$ \\
\hline
\end{tabular}

Source: Researcher's computations (2020) 
International Journal of Business and Management Review

Vol.8, No.4, pp.78-100, July 2020

Published by ECRTD-UK

Print ISSN: 2052-6393(Print), Online ISSN: 2052-6407(Online)

DATA ANALYSIS, RESULTS AND DISCUSSIONS

Table 1: The Dependent Variable Summary Statistics

\begin{tabular}{|l|c|c|c|c|c|}
\hline Variable & Obs. & Mean & Std. Dev. & Min & Max \\
\hline NPBIT & 120 & 43.495 & 67.115 & -279.786 & 243.294 \\
\hline EVA & 120 & 158.857 & 137.086 & 16.243 & 602.903 \\
\hline ROA & 120 & 0.013 & 0.033 & -0.242 & 0.106 \\
\hline CR & 120 & 0.029 & 0.031 & 0.000 & 0.193 \\
\hline LIQR & 120 & 0.288 & 0.214 & 0.019 & 1.632 \\
\hline INSRK & 120 & 0.952 & 1.681 & -9.832 & 11.000 \\
\hline MKTR & 120 & 1135.961 & 3275.994 & 29.530 & 23643.880 \\
\hline FRMSIZ & 120 & 21.021 & 0.884 & 18.869 & 22.878 \\
\hline
\end{tabular}

Source: Researcher's computations (2020)

Table 1 displays the numbers of observations, mean, standard deviation, minimum and maximum values for each of the variables in the model. The variables that constitute the dependent variables are; Profitability $\{$ NPBIT $\}$, Economic Value Added $\{$ EVA $\}$ and Return on Assets $\{$ ROA $\}$, while Credit Risk \{CR , Liquidity Risk \{LIQR \}, Insolvency Risk \{INSRK\} and Market Risk \{MKTR are elements of the explanatory variables: but the Firm Size \{FRMSIZ\} is the control variable. In Table 1, the average value of the Profitability $\{$ NPBIT $\}$ was N43.495b, which suggests that the banks are able to earn about N43.50billion before tax Taxation; in addition to this, the measure of rate of dispersion is this variable's value is given as 67.115 , which is a bit far from the mean, thus this suggests a bit rising in the Profitability $\{$ NPBIT $\}$ of the companies for the year. The minimum and the maximum values of Profitability \{NPBIT \} are observed to be -N279.786 and N243.294. The average value of the Economic Value Added was N158.857b from 120 observations. The obtained minimum and maximum Economic Value Added values are N16.243b and N602.903b respectively, with the rate by which these values are spread out from one another being 137.086. This means that the average measure of a company's financial performance based on the residual wealth of the companies is considerably high. The Return on Assets $\{$ ROA $\}$ has 0.013 mean value (about $1.3 \%$ ), with its measure of volatility i.e. the standard deviation equals 0.033 ; which implies that the percentage of profit been made by the companies in respect to overall assets is 1.3 . The maximum and minimum values are -0.242 and 0.106 respectively. The number of observation carried out remains 120. The average value of Credit Risk is 0.029, i.e. debt that may arise from a borrower failing to make required payments from this study is approximately $2.9 \%$, with the rate of variation a bit closed to its mean, which is seen as 0.031 . The lowest and the highest values recorded are in range 0.0 to 0.193 . This short term debt obligated variable has 0.288 average values with standard deviation being 0.214; which means, the short term security of the banks is about $28.8 \%$ of the total deposit during the period of the study. Liquidity Risk spreads out in the range of 0.019 and N1.632: in other words, Liquidity observed maximum and minimum values are N0.019 and N1.632 respectively.

Insolvency Risk is seen from Table 1 , to have an average value of 0.952 , from 120 observations. The standard deviation which is the measure of rate of variation is observed to be 1.681. All these 
were obtained from set of values that spread out in the range of -9.832 to 11.000 . The average value of this Market Risk as observed was N1135.96m, with rate of change in its values being $3275.99 \mathrm{~m}$. It has its minimum and maximum values as $\mathrm{N} 29.530 \mathrm{~m}$ and $\mathrm{N} 23,643.880$ million respectively. The average value of Firm Size is 21.021 with 0.884 standard deviation, which suggests that there exists wide variation between the firms. Furthermore, the minimum and maximum values are approximately 19 and 23 respectively: with observation number remaining 120.

\section{The Correlation Matrix}

This showcases the kind of relationship/association that exists between the dependent variables, the explanatory variables (independent variables) and the control variable. In other words, in more elaborate manner; this subsection's presentation reveals whether there exists bivariate relationship among the dependent, independent (explanatory variable) and the control variables and if this association is not so great to the point of posing multicollinearity problem.

Table 2 Correlation Matrix

\begin{tabular}{|l|l|l|l|l|l|l|l|l|}
\hline Variable & NPBIT & EVA & ROA & CR & LIQR & INSRK & MKTR & FRMSIZ \\
\hline NPBIT & 1.0000 & & & & & & & \\
\hline EVA & 0.6958 & 1.0000 & & & & & & \\
\hline ROA & 0.6531 & 0.3178 & 1.0000 & & & & & \\
\hline CR & - & - & -0.3401 & 1.0000 & & & & \\
\hline LIQR & 0.2903 & 0.1078 & & & & & \\
\hline INSRK & - & 0.2698 & 0.2111 & -0.2274 & 1.0000 & & & \\
\hline MKTR & 0.1161 & 0.0122 & -0.0188 & 0.1647 & -0.1054 & 1.0000 & & \\
\hline FRMSIZ & 0.6417 & 0.9161 & 0.2638 & -0.1100 & 0.3146 & -0.0213 & 0.1903 & 1.0000 \\
\hline
\end{tabular}

Source: Researcher's computations (2020)

It's obvious from Table 2, that the correlation coefficients of the chosen variables have -0.3401 lowest value and 0.9161 highest value. The kind of associations that exist between the dependent variables and the explanatory variable have -0.3401 lowest value coefficients and also 0.9161 maximum coefficient value; which is the same as when taking general overview. Explaining briefly the associations between the dependent variable and the explanatory variables (with the control variable inclusive): since the sign of the coefficient connotes the direction of relationship and a correlation that approaches zero (0) indicates no linear relationship between variable; Profitability $\{\mathrm{NPBIT}\}$ is in positive association with Liquidity Risk $\{\mathrm{LIQR}\}$, Market Risk \{MKTR $\}$ and Firm Size $\{$ FRMSIZ\}, but in negative association with the Credit Risk $\{\mathrm{CR}\}$ as well as Insolvency Risk \{INSRK\}. Meanwhile, Economic Value Added $\{$ EVA $\}$ is in positive association with all the explanatory variables with the exception of Credit Risk $\{\mathrm{CR}\}$. Furthermore, Return on Assets $\{$ ROA $\}$ (the third dependent variable) engages in negative 
relationship with the majority of explanatory variables (control variable inclusive), with the exception of Liquidity Risk $\{$ LIQR $\}$.

\section{Regression Results and test of Hypothesis}

\section{Hypothesis One}

Research Objective: To investigate the effect of financial risk on profitability of DMBs in Nigeria;

Table 3: Test of Hypotheses One

\begin{tabular}{|c|c|c|}
\hline \multirow{2}{*}{ Variable } & $\begin{array}{c}\text { Fixed effect regression with Driscoll- } \\
\text { Kraay standard errors }\end{array}$ & $\begin{array}{c}\text { Random effect regression with } \\
\text { normal standard errors }\end{array}$ \\
\hline & $\begin{array}{c}\text { Coeff. [t-test] } \\
P \text {-value }\end{array}$ & $\begin{array}{c}\text { Coeff. [t-test] } \\
P \text { - value }\end{array}$ \\
\hline \multirow[t]{3}{*}{ CR } & $-13.0495 * *[-2.9560]$ & $-7.6165 * * *[-3.5420]$ \\
\hline & 0.0131 & 0.0004 \\
\hline & $-0.1561[-0.4374]$ & $-0.2096[-1.0365]$ \\
\hline LIQR & 0.0131 & 0.3000 \\
\hline \multirow{2}{*}{ INSRK } & $-0.0161[-0.3338]$ & $-0.0349[-1.3832]$ \\
\hline & 0.7448 & 0.1666 \\
\hline \multirow{2}{*}{ MKTR } & $0.0384[0.5720]$ & $0.0273[0.9364]$ \\
\hline & 0.5788 & 0.3491 \\
\hline \multirow{2}{*}{ FRMSIZ } & & $0.4289 * * *[7.0038]$ \\
\hline & & 0.0000 \\
\hline \multirow{2}{*}{ Constant } & 0.6555 [1.6428] & $-8.4227 * * *[-6.5206]$ \\
\hline & 0.1287 & 0.0000 \\
\hline \multirow{4}{*}{ 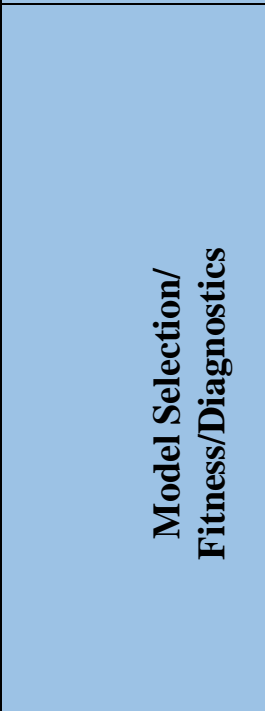 } & Observation:120 & Observation:120 \\
\hline & $\begin{array}{c}\text { F-stat./Wald-Chi2 }(\text { Pval })=3.331 \\
(0.048) ; \mathbf{R}^{\mathbf{2}}=0.166 ; \text { Adj. } \mathbf{R}^{\mathbf{2}}=0.124\end{array}$ & $\begin{array}{c}\text { F-stat. } / \text { Wald-Chi }{ }^{\mathbf{2}}(\mathbf{P v a l})=75.63 \\
(0.000) ; \mathbf{R}^{\mathbf{2}}=0.388 ; \text { Adj. } \mathbf{R}^{\mathbf{2}}=0.315\end{array}$ \\
\hline & $\begin{array}{c}\text { Hausman Test }(\text { Pval })=17.74 \\
(0.001) ; \\
\text { LM Test }(\text { Pval })= \\
84.58(0.000)\end{array}$ & $\begin{array}{c}\text { Hausman Test }(\text { Pval })=6.28(0.280) \\
\text { LM Test }(\text { Pval })= \\
64.65(0.000)\end{array}$ \\
\hline & $\begin{array}{c}\text { Heteros. Test (Pval) }=2009.01 \\
(0.000) ; \\
\text { Pesaran's CD Test }(\text { Pval })=10.885 \\
(0.000) ; \\
\text { Autocorrelation }(\text { Pval })=0.884 \\
(0.372)\end{array}$ & $\begin{array}{c}\text { Heteros. Test }(\text { Pval })=1.04(0.308) \\
\text { Pesaran's CD Test }(\text { Pval })=2.787 \\
(0.174) ; \\
\text { Autocorrelation }(\text { Pval })=1.377 \\
(0.271)\end{array}$ \\
\hline
\end{tabular}

In achieving the above objectives; the results of regression analyses estimated with Profitability 
International Journal of Business and Management Review

Vol.8, No.4, pp.78-100, July 2020

Published by ECRTD-UK

Print ISSN: 2052-6393(Print), Online ISSN: 2052-6407(Online)

(NPBIT) as dependent variable are presented in Table 3. The models have been estimated using Fixed and Random effect regression with Driscoll-Kraay standard errors and normal standard errors respectively.

Hausman and LM Tests: As in Table 3, the Fixed and Random Effect estimators used in this study are as subjected by Hausman specification tests' results indicated that under $H_{0}$ the preferred models are fixed and random effect models. Furthermore, the significant value (Pvals < 0.05) of LM tests' results show that panel effect exists, thus the recommended panel regression approach is appropriate.

Heteroscedasticity, Pesaran's CD and Autocorrelation Tests: In an effort to check whether the chosen models satisfy the regression assumptions and be able to rely on the results, Heteroscedasticity, Pesaran's CD and Autocorrelation Tests were carried out. From the result in Table 3, the heteroscedasticity test carried out to ascertain whether the residual has constant variance or not, show statistically insignificant value (Pvals > 0.05) only in column (2) which indicates that the model with control variable has constant variances. In other words, it means that the model is free from heteroscedasticity problem. Similarly, Pesaran CD Test value appears insignificant in the model with control variable (Pvals > 0.05) suggesting no cross sectional dependence. Besides, for Serial autocorrelation test, the obtained values are insignificant (Pvals > 0.05) which means that there is no presence of first order autocorrelation among the residuals in both models. These outputs justifed the use of Fixed and Random effect regression with and without Driscoll-Kraay standard errors in columns (1) and (2) respectively.

Model (1):In Table 3 we reported the estimates from the regression analysis that was first carried out by regressing Profitability (NPBIT) on Financial risk indicator in order to test hypothesis one (1). From the Table 3, the F-stat./Wald-Chi2 (Pval) = $3.331(0.048)$ indicates that the model is statistically significant. Additionally, the Adjusted R-squared of the regression model is 0.124 (i.e. about 12.4 per cent) suggesting that financial risk indicators are explaining about 12.4 per cent of variations in Profitability.

Furthermore, the estimated parameters; particularly that of Credit Risk (CR) is seen to be negative and statistically significant at alpha $=0.05$. This means that Credit Risk $(\mathrm{CR})$ has negative and significant effect on Profitability (NPBIT) $[\beta=-13.0495$; Pval $=0.013]$. It also means that a unit increase in CR causes NPBIT to fall by 13.050 units. On the contrary, the result shows that Liquidity Risk (LIQR) $[\beta=-0.156$; Pval = 0.6703] and Insolvency Risk (INSRK) $[\beta=-0.016$; Pval $=0.745]$ have negative signs that are statistically insignificant at alpha $=0.05$. These means that the two (2) financial risk indicators have no significant effect on Profitability (NPBIT). Similarly, the result shows that Market Risk $($ MKTR) $[\beta=0.038$; Pval $=0.5720]$ has insignificant and positive effect on Profitability (NPBIT) at alpha $=0.05$ level.

Model (2): In a similar way, the result of regression analysis carried out by regressing Profitability (NPBIT) on financial risk indicator and Firm Size (FS) in order to test hypothesis four (4) are presented in the Table 3. The F-stat./Wald-Chi2 (Pval) $=75.63(0.000)$ is suggesting that the model is statistically significant. Again, the Adjusted R-squared of the regression model is 0.315 (i.e. 
31.5 per cent) indicates that about 31.5 per cent of the variations in Profitability (NPBIT) are jointly explained by Financial Risk indicators and Firm Size (FRMSIZ). Comparing the adjusted Rsquared of Model (1) to Adjusted R-squared of Model (2), it is clear that the Adjusted R-squared in Model (2) has improved. In other words, Model (2) has more explanation power than Model (1). Also, the coefficient of Credit Risk $(C R)[\beta=-7.617$; Pval $=0.000]$ becomes more significant at alpha level of 0.01 though; other Financial Risk indicators remain insignificant. Additionally, the control variable (FRMSIZ) $[\beta=0.430$; Pval $=0.000]$ has positive and significant effect on the Profitability at alpha $=0.01$. This means that increase in size of the banks causes increase in profitability.

Decision: The null hypothesis one $\left(\mathrm{H}_{\mathrm{o} 1}\right)$ was framed to test the effect of financial risk on profitability of listed banks in Nigeria; besides, the null hypothesis four $\left(\mathrm{H}_{\mathrm{o} 4}\right)$ was framed as "Firm size has no effect in the relationship between financial risk and profitability of DMBs in Nigeria". Based on the Adjusted R-squared values (0.124 and 0.315) and the significant F-stat./Wald-Chi2 $($ Pval $)=3.331(0.048)$ and $75.63(0.000)$ for Models (1) and (2) respectively, the null hypotheses one $\left(\mathrm{H}_{\mathrm{o} 1}\right)$ and four $\left(\mathrm{H}_{\mathrm{o} 4}\right)$ are rejected at alpha $=0.01$. Therefore, it is safe to conclude that financial risk has significant effect on profitability (NPBIT) of DMBs in Nigeria and Firm size has effect on the relationship between financial risk and profitability of DMBs in Nigeria.

\section{Test of Hypotheses Two}

(Ho2): There is no significant effect of financial risk on economic value added of DMBs in Nigeria.

Table 4: Test of Hypotheses Two

\begin{tabular}{|c|c|c|}
\hline \multirow{2}{*}{ Variable } & $\begin{array}{l}\text { Fixed effect regression with } \\
\text { Driscoll-Kraay standard errors }\end{array}$ & $\begin{array}{c}\text { Random effect regression with } \\
\text { normal standard errors }\end{array}$ \\
\hline & $\begin{array}{c}\text { Coeff. [t-test] } \\
P \text {-value }\end{array}$ & $\begin{array}{c}\text { Coeff. [t-test }] \\
P \text { - value }\end{array}$ \\
\hline CR & $\begin{array}{c}-7.0789 * * *[-3.4475] \\
0.0055\end{array}$ & $\begin{array}{c}0.0901[0.0600] \\
0.9522\end{array}$ \\
\hline \multirow{2}{*}{ LIQR } & $0.0264[0.0502]$ & $-0.1589[-1.0991]$ \\
\hline & 0.9609 & 0.2717 \\
\hline \multirow{2}{*}{ INSRK } & 0.0444 [1.2689] & $-0.00004[-0.0022]$ \\
\hline & 0.2307 & 0.9982 \\
\hline \multirow{2}{*}{ MKTR } & $0.0369[0.3306]$ & $0.0140[0.6680]$ \\
\hline & 0.7472 & 0.5041 \\
\hline \multirow{2}{*}{ FRMSIZ } & & $0.8418 * * *[19.4344]$ \\
\hline & & 0.0000 \\
\hline \multirow{3}{*}{ Constant } & $4.6825 * * *[0.5701]$ & $-12.9949 * * *[-14.2455]$ \\
\hline & 0.0000 & 0.0000 \\
\hline & Observation:120 & Observation:120 \\
\hline
\end{tabular}


International Journal of Business and Management Review

Vol.8, No.4, pp.78-100, July 2020

Published by ECRTD-UK

Print ISSN: 2052-6393(Print), Online ISSN: 2052-6407(Online)

\begin{tabular}{|c|c|c|}
\hline 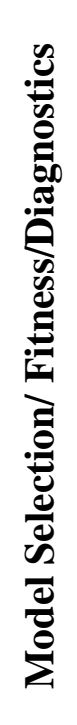 & $\begin{array}{c}\text { F-stat./Wald-Chi2 (Pval) }=7.702 \\
\begin{array}{c}(0.003) ; R^{2}=0.065 ; \text { Adj. } \mathbf{R}^{2}= \\
0.045\end{array} \\
\text { Hausman Test (Pval) }=18.17 \\
(0.011) ; \\
\text { LM Test (Pval) }= \\
92.15(0.000) \\
\text { Heteros. Test (Pval) }=485.28 \\
(0.000) ; \\
\text { Pesaran's CD Test (Pval) }= \\
\text { 12.787 (0.000); } \\
\text { Autocorrelation (Pval) }=0.572 \\
(0.469)\end{array}$ & $\begin{array}{c}\text { F-stat./Wald-Chi2 }(\text { Pval })=407.6 \\
\begin{array}{c}(0.000) ; \mathbf{R}^{2}=0.760 ; \text { Adj. } \\
0.648\end{array} \\
\text { Hausman Test (Pval) }=2.27 \\
(0.810) ; \\
\text { LM Test (Pval) }= \\
26.24(0.000) \\
\text { Heteros. Test (Pval) }=0.26 \\
(0.613) ; \\
\text { Pesaran's CD Test (Pval) }=2.450 \\
(0.114) ; \\
\text { Autocorrelation (Pval) }=0.009 \\
(0.928)\end{array}$ \\
\hline
\end{tabular}

Hausman and LM Tests: In Table 4, the Fixed and Random Effect estimators used in this study are as suggested by Hausman specification tests' results suggest that the preferred models under $H_{0}$ are fixed and random effect models. Furthermore, the significant value (Pvals < 0.05) of LM tests' results showed that panel effect exists, thus the recommended panel regression approach is appropriate.

Heteroscedasticity, Pesaran's CD and Autocorrelation Tests: Again, in checking whether the chosen models satisfy the regression assumptions and can be relied, Heteroscedasticity, Pesaran's CD and Autocorrelation Tests were carried out. From the result in Table 4, the heteroscedasticity test carried out to ascertain whether the residual has constant variance or not, show statistically insignificant value (Pvals > 0.05) only in column (2) which indicates that the model with control variable has constant variances. In other words, it means that the model is also free from heteroscedasticity problem. Similarly, Pesaran CD Test value appears insignificant in the model with control variable (Pvals > 0.05) suggesting no cross sectional dependence. Besides, for Serial autocorrelation test, the obtained values are insignificant (Pvals $>0.05$ ) which means that there is no presence of first order autocorrelation among the residuals in both models. These outputs explain the reason for using Fixed and Random effect regression with and without Driscoll-Kraay standard errors in columns (1) and (2) respectively..

Model (1):In Table 4. the reported estimates from the regression analysis that was carried out using regressing Economic Value Added (EVA) on Financial risk indicator in order to test hypothesis one (1) show the F-stat./Wald-Chi2 with the associated Pval to be 7.702 (0.003). This simply means that the model is statistically significant and can be relied upon at alpha $=0.01$. Furthermore, the Adjusted R-squared of the regression model is found to be 0.045 (i.e. about 4.5 per cent) suggesting that financial risk indicators jointly account for about 4.5 per cent of variations in 
International Journal of Business and Management Review

Vol.8, No.4, pp.78-100, July 2020

Published by ECRTD-UK

Print ISSN: 2052-6393(Print), Online ISSN: 2052-6407(Online)

Profitability.

Moreover, the estimated parameters; particularly that of Credit Risk (CR) showed negative sign just as in the previous model. This negative coefficient is found to be statistically significant at alpha $=0.01$. This means that Credit Risk $(\mathrm{CR})$ has negative and significant effect on Economic Value Added (EVA) $[\beta=-7.0789$; Pval $=0.006]$. It also means that a unit increase in CR causes about 7.079units reductions in EVA. On the contrary, the result showed that Liquidity Risk (LIQR) $[\beta=0.0264$; Pval $=0.961]$, Insolvency Risk (INSRK) $[\beta=-0.016$; Pval $=0.745]$ and Market Risk $[\beta=0.0369$; Pval $=0.747]$ have positive signs that are statistically insignificant at alpha $=0.05$. These means that the three (3) financial risk indicators have no significant effect on Economic Value Added (EVA).

Model (2): Correspondingly, the result of regression analysis carried out by regressing Economic Value Added (EVA) on financial risk indicator and Firm Size (FS) in order to test whether there is no significant effect of financial risk with control variable of firm size on economic value added of DMBs in Nigeria are presented in the Table 4. The F-stat./Wald-Chi2 (Pval) $=407.6(0.000)$ is suggesting that the model is statistically significant. Again, the Adjusted R-squared of the regression model is 0.648 (i.e. 64.8 per cent) indicates that about 64.8 per cent of the changes in Economic Value Added (EVA) are jointly explained by Financial Risk indicators and Firm Size (FRMSIZ). Relating the adjusted R-squared of Model (1) to Adjusted R-squared of Model (2), it is evident that the Adjusted R-squared in Model (2) has been enriched. In other words, Model (2) has more explanation power than Model (1) which is due to the inclusion of Firm Size in the model though; the coefficient of Credit Risk $(C R)[\beta=0.0901$; Pval $=0.9522]$ becomes positive and that of LIQR and INSRK negatives but statistically insignificant at alpha level of 0.05 . In addition, the control variable (FRMSIZ) $[\beta=0.842$; Pval $=0.000]$ has positive and significant effect on the Economic Value Added at alpha $=0.01$ as evident from the result in Table 4. This is telling us that increase in size of the banks causes increase in EVA.

Decision: The null hypothesis two $\left(\mathrm{H}_{\mathrm{o} 2}\right)$ was framed to test whether there is no significant effect of financial risk on economic value added of DMBs in Nigeria; besides, the null hypothesis five $\left(\mathrm{H}_{05}\right)$ was framed as "There is no significant effect of financial risk with control variable of firm size on economic value added of DMBs in Nigeria.". Based on the Adjusted R-squared values (0.045 and 0.648) and the significant F-stat./Wald-Chi2 (Pval) = $7.702(0.003)$ and $407.6(0.000)$ for Models (1) and (2) respectively, the null hypotheses two $\left(\mathrm{H}_{\mathrm{o} 2}\right)$ and five $\left(\mathrm{H}_{\mathrm{o} 5}\right)$ are rejected at alpha $=0.01$. Thus, the study concluded that there is significant effect of financial risk on economic value added of DMBs in Nigeria and there is no significant effect of financial risk with control variable of firm size on economic value added of DMBs in Nigeria.

\section{Hypothesis three}

Research Objective: To ascertain the effect of financial risk on return on assets of DMBs in Nigeria; 
Table 5: Test of Hypotheses Three

\begin{tabular}{|c|c|c|}
\hline \multirow{2}{*}{ Variable } & $\begin{array}{l}\text { Fixed effect regression with } \\
\text { Driscoll-Kraay standard errors }\end{array}$ & $\begin{array}{l}\text { Fixed effect regression with } \\
\text { Driscoll-Kraay standard errors }\end{array}$ \\
\hline & $\begin{array}{l}\text { Coeff. }[\text { t-test }] \\
P \text {-value }\end{array}$ & $\begin{array}{c}\text { Coeff. }[\text { t-test }] \\
P \text {-value }\end{array}$ \\
\hline \multirow{3}{*}{$\mathrm{CR}$} & $-0.9647 *[-2.2995]$ & $-0.9587 * *[-2.2562]$ \\
\hline & 0.0421 & 0.0454 \\
\hline & $-0.0018[-0.1974]$ & $-0.0019[-0.2293]$ \\
\hline LIQR & 0.8471 & 0.8228 \\
\hline \multirow{2}{*}{ INSRK } & 0.0008 [0.2971] & $0.0008[0.2762]$ \\
\hline & 0.7719 & 0.7875 \\
\hline \multirow{2}{*}{ MKTR } & $-0.0006[-0.6312]$ & $-0.0006[-0.6188]$ \\
\hline & 0.5408 & 0.5486 \\
\hline FRMSIZ & & $\begin{array}{c}0.0007[0.1528] \\
08813\end{array}$ \\
\hline \multirow[b]{2}{*}{ Constant } & $0.0449 * *[2.5900]$ & $\begin{array}{c}0.8813 \\
0.0310[0.3404]\end{array}$ \\
\hline & 0.0251 & 0.7400 \\
\hline \multirow{6}{*}{ 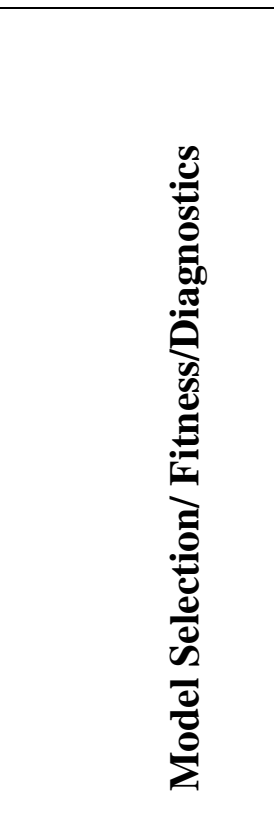 } & Observation:120 & Observation:120 \\
\hline & $\begin{array}{c}\text { F-stat./Wald-Chi2 }(\text { Pval })=3.562 \\
(0.043) ; \mathbf{R}^{2}=0.249 ; \text { Adj. } \mathbf{R}^{2}= \\
0.224\end{array}$ & $\begin{array}{c}\text { F-stat./Wald-Chi2 }(\text { Pval })=3.642 \\
(0.035) ; \mathbf{R}^{2}=0.249 ; \mathbf{A d j} . \mathbf{R}^{2}= \\
0.228\end{array}$ \\
\hline & $\begin{array}{c}\text { Hausman Test }(\text { Pval })=13.90 \\
(0.008) ; \\
\text { LM Test }(\text { Pval })= \\
12.81(0.000)\end{array}$ & $\begin{array}{c}\text { Hausman Test }(\text { Pval })=11.36 \\
(0.045) ; \\
\text { LM Test }(\text { Pval })= \\
7.21(0.004)\end{array}$ \\
\hline & $\begin{array}{c}\text { Heteros. Test }(\text { Pval })=5053.29 \\
(0.000)\end{array}$ & $\begin{array}{l}\text { Heteros. Test }(\text { Pval })=5703.70 \\
(0.000):\end{array}$ \\
\hline & $\begin{array}{c}\text { Pesaran's CD Test }(\text { Pval })=4.819 \\
(0.000) ;\end{array}$ & $\begin{array}{c}\text { Pesaran's CD Test }(\text { Pval })=4.663 \\
(0.000) ;\end{array}$ \\
\hline & $\begin{aligned} \text { Autocorrelation }(\mathbf{P v a l}) & =1.265 \\
(0.299) & \end{aligned}$ & $\begin{aligned} \text { Autocorrelation }(\text { Pval }) & =0.974 \\
(0.349) & \end{aligned}$ \\
\hline
\end{tabular}

In achieving the above stated objectives; the results of regression analyses estimated with return on Assets ROA as the dependent variable are presented in Table 4.. Both models have already been estimated using Fixed effect regression with Driscoll-Kraay standard errors.

Hausman and LM Tests: From Table 5, Hausman specification tests' sresult suggests the choice of Fixed Effect estimators used for both models in this study. The null hypothesis is that the errors 
International Journal of Business and Management Review

Vol.8, No.4, pp.78-100, July 2020

Published by ECRTD-UK

Print ISSN: 2052-6393(Print), Online ISSN: 2052-6407(Online)

are not correlated with the regressors. The significance (Pvals $<0.05$ ) of the test result in column (1) and also the significance (Pvals $<0.05$ ) of the test result in column (2) suggest that under $H_{0}$ the preferred models are fixed effect models. In addition to this, looking at the LM tests' result, the significance (Pvals < 0.05) of LM tests' results showed that panel effect exists, thus the recommended panel regression approach is appropriate.

Heteroscedasticity, Pesaran's CD and Autocorrelation Tests: In an attempt to check whether the chosen models satisfy the regression assumptions and to be able to rely on the results, Heteroscedasticity, Pesaran's CD and Autocorrelation Tests were conducted. From the heteroscedasticity test results obtained, as it appears in Table 5, in order to affirm whether the residual has constant variance or not; the heteroscedasticity test gives significant values (Pvals < 0.05) in both column (1) and (2), which implies that both models do not have constant variances. In other words, it means that the regression models are not free from heteroscedasticity problem. Similarly, Pesaran CD Test values appear significant in both models (Pvals < 0.05) depicting cross sectional dependences. For Serial autocorrelation test, the obtained results are insignificant (Pvals $>0.05$ ) which connotes that there is no presence of first order autocorrelation among the residuals in both models. These outputs justify the use of fixed effect regression with Driscoll-Kraay standard errors in both columns (1\&2).

Model (1): Explaining this model from Table 5, the estimates from the regression analysis that was first conducted by regressing Return on Assets (ROA) on Financial risk indicator in order to test hypothesis one (1) is reported. Also, the F-stat./Wald-Chi2 (Pval) = $3.562(0.043)$ that suggests the significance of this model, the Adjusted R-squared of the regression model which is 0.224 (about 22.4 per cent) suggesting that financial risk indicators are explaining about 22.4 per cent of changes in Return on Assets are as well reported.

In addition to this, the estimated Credit Risk (CR) is observed to be negative and statistically significant at alpha $=0.05$. This means that Credit Risk $(\mathrm{CR})$ has negative and significant effect on Return on Assets (ROA) [ $\beta=-0.9647$; Pval $=0.0421]$. It also means that every unit increase in CR causes ROA to fall by 0.9647 units. Liquidity Risk (LIQR) $[\beta=-0.0018$; Pval $=0.8471]$ and Insolvency Risk (INSRK) $[\beta=0.0008$; Pval $=0.7719]$ have negative and positive signs that are statistically insignificant at alpha $=0.05$ respectively. This is to say that the two (2) financial risk indicators have no significant effect on Return on Assets (ROA). Similar to these is the result of Market Risk (MKTR) $[\beta=-0.0006$; Pval $=0.5408]$, which has insignificant and negative effect on Assets (ROA) at alpha $=0.05$ level.

Model (2): Just exactly as it happened to model (1), the result of regression analysis conducted by regressing Return on Assets (ROA) on financial risk indicator and control variable Firm Size (FS) in order to test hypothesis four (6) are recorded and presented in the Table 5. The F-stat./WaldChi2 (Pval) $=3.642(0.035)$ suggests that the model is statistically significant at $5 \%$ significant level. The Adjusted R-squared of the regression model which is 0.228 (about 22.8 per cent) which indicates about 22.8 per cent of changes in Return on Assets (ROA) are jointly explained by Financial Risk indicators and Firm Size (FRMSIZ). From comparison of the two Adjusted Rsquared of Model (1) to Adjusted R-squared of Model (2), it is obvious that the Adjusted R-squared 
International Journal of Business and Management Review

Vol.8, No.4, pp.78-100, July 2020

Published by ECRTD-UK

Print ISSN: 2052-6393(Print), Online ISSN: 2052-6407(Online)

in Model (2) has improved. In other words, Model (2) has more explanation power than Model (1). Also, the control variable (FRMSIZ) $[\beta=0.0007$; Pval $=0.8813]$ has positive and insignificant effect on the Return on Assets (ROA) at alpha $=0.05$. This is an indication that increase in size of the banks leads to increase in Return on Assets.

Decision: The null hypothesis one $\left(\mathrm{H}_{03}\right)$ was phrased to test the effect of Financial risk on return on assets of DMBs in Nigeria; besides, the null hypothesis four $\left(\mathrm{H}_{\mathrm{o} 6}\right)$ was phrased as "Financial risk with control variable of firm size has no significant effect on return on assets of DMBs in Nigeria". Based on the Adjusted R-squared values (0.224 and 0.228) and the significant Fstat./Wald-Chi2 (Pval) = 3.562 (0.043) and 3.642 (0.035) for Models (1) and (2) respectively, the null hypotheses one $\left(\mathrm{H}_{03}\right)$ and four $\left(\mathrm{H}_{06}\right)$ are rejected at alpha $=0.01$. Hence, we conclude that Financial risk has significant effect on return on assets of DMBs in Nigeria and Financial risk with control variable of firm size has significant effect on return on assets of DMBs in Nigeria.

\section{DISCUSSION}

The crisis rocking the performance of DMBs is a global issue that requires a lasting solution, Financial risk in DMB is actually somewhat challenging and different from other risks facing banks, as it is not only systemic in nature, but asymmetric, reducing banks financial and nonfinancial performances leading to huge losses, loss of confidence of both investors and depositors alike. Hence, the study examined the effect of financial risks on financial performance using the identified explanatory variables of financial risks of credit risks, Insolvency risk, Liquidity Risk and Market Risk covering a period of 12 years (2007-2018). The methodology of the study adopted ex-post facto research design. While the population of the study were nineteen DMBs, the study sampled examined the sample size of ten (10). The panel regression models estimated using Unobserved Effects Model (UEM), while the result of the Hausman test indicated between fixed effect model and random effect model.

The study findings showed that Credit Risk is seen to be negative and statistically significant to DMBs at 0.05 significant level. While both Liquidity Risk and Insolvency Risk were inversely and insignificant to banks profitability, Market Risk has insignificant and positive effect on banks Profitability. The second model in the inclusion of firm size showed that Credit Risk is negative and significant to profitability. However, Firm size has positive and significant effect on the Profitability.

Also, on the model between financial risk and economic value added, Credit Risk was found to be negative and statistically significant to Economic Value Added. On the contrary, the result also showed that Liquidity Risk and Market Risk have positive signs that are statistically insignificant to Economic Value Added. While Insolvency Risk have negative and insignificant effect on Economic Value Added. The results of firm size inclusive also showed that Credit Risk has positive but insignificant effect on Economic Value Added. In addition, the control variable of firm size has positive and significant effect on the Economic Value Added. Lastly, on the effect of financial risk and banks return on assets, study showed that credit risk posited a negative and significant effect on Return on Assets. Liquidity Risk and insolvency Risk have negative and 
International Journal of Business and Management Review

Vol.8, No.4, pp.78-100, July 2020

Published by ECRTD-UK

Print ISSN: 2052-6393(Print), Online ISSN: 2052-6407(Online)

positive signs that are statistically insignificant to Return on Assets. Similarly, market risk had negative but insignificant effect on Return on Assets. Also, with the control variable of firm size, firm size has positive and insignificant effect on the Return on Assets.

Through practical investigation, break down and collation of results, the present study illustrates that credit risk inversely influence DMBs performance with a clear indication of statistical significant on banks profitability, return on assets and banks economic value added. More so, the insolvency and liquidity risk though have uncertainty effect on DMBs performance, however, they were found to be insignificant determinant of banks performance among DMBs in Nigeria. This result gives a clear indication to bank managers and the sector as a whole, that undertaking risks funding ventures will result in higher funding losses, with the consequence to banks, of considerable depletion of resources.

Subsequent to the analysis and discussion, the following recommendations were made.

i. The study recommends continuing follow-up on non-performing loans because it leads to a loss to the banks and a deterioration of their financial position. In fact, it leads to a poor quality asset base.

ii. Better risk management in terms of managed fund, reduction in cost of bad and doubtful loans and debt equity ratio results in better banks performance. Thus, it is of crucial importance that banks practice prudent risk management of their assets in order to maximize investors' wealth.

iii. Bank's managers should improve on the management of insolvency risk through regular review of credit limits of their customers as well as credible practice of credit control procedure.

iv. It is fundamental for DMBs in Nigeria to practice scientific credit risk management, improve their efficacy in credit analysis and loan management to secure as much as possible their assets, and minimize the high incidence of non-performing loans and their negative effects on financial performance.

\section{References}

Abdolazim, A. (2014). Examine the relationship between financial performance and capital structure, free cash and operational risks in governmental companies. Journal of Educational and Management Studies, 4(3), 545-549.

Achumba, I. C., Ighomereho, O. S., \& Akpor-Robaro, M. O. M. (2013). Security challenges in Nigeria and the implications for business activities and sustainable development. Journal of Economics and Sustainable Development, 4(2), 79-99.

Ahmad, B. (2017). Effect of credit risk, liquidity risk, and market risk banking to profitability Bank; Study on devised banks in Indonesia Stock Exchange. European Journal of Business and Management, 9(29), 222-231.

Arroyave, J. (2018). A comparative analysis of the effectiveness of corporate bankruptcy prediction models based on financial ratios: Evidence from Colombia. Journal of International Studies, 11(1), 273-287. 
International Journal of Business and Management Review

Vol.8, No.4, pp.78-100, July 2020

Published by ECRTD-UK

Print ISSN: 2052-6393(Print), Online ISSN: 2052-6407(Online)

Deposit Money banks in Ethiopia: European Journal of Business and Economics, 4(2),

El-Ansary, O. (2019). Predicting financial distress for listed Middle East and Northern Africa firms. International Journal of Accounting and Financial Reporting, 9(2), 51-75.

Enofe, A., Ekpule, G., Onobun, S., \& Onyekweni, V. (2015). Ethical challenges and financial performance in the Nigeria banking sector. Research Journal of Finance and Accounting, 6(1), 1-11.

Epetimehin, F. M \& Obafemi, F. (2015). Financial risk management and the financial sector development: an overview. International Journal of Economics, Commerce and Management, 3(3), 23480386

Ezejiofor, R. A., Adigwe, P. K., \& John-Akamelu, R. C. (2015). The credit management on liquidity and profitability position of manufacturing company in Nigeria. European Journal of Research and Reflection in Management Sciences, 3(3), 32-48.

Fan, L., \& Yijun, Z. (2014). The impact of credit risk management on profitability of Deposit Money banks: a study of Europe. Journal of Umeå School of Business and Economics, l(1), 2-10.

Gadzo, S. G., Kportorgbi, H. K., \& Gatsi, G. J. (2019). Credit risk and Financial risk on financial performance of universal banks in Ghana: A partial least squared structural equation model approach. Cogent Economics \& Finance, 7(1), 1-16

Haile1, A., Getacher, T., \& Tesfay, H. (2014). Financial performance analysis of selected

Halkos, G., \& Salamouris, D. (2004). Efficiency measurement of the Greek Deposit Money banks

Hawaldar, I. T., Rajesha T. M., Lokesha, J., \& Kumar, A. (2017). Impact of financial and oil price crisis on the financial performance of selected banks in Bahrain. International Journal of Economic Research, 14(18), 83-96.

Idekwulim, C. (2014). Teach yourself group accounting. Piccas Global Concept, (1 ${ }^{\text {st }}$ Ed). Yaba Lagos Nigeria.

industry on economic growth of Nigeria. Master Dissertaion> University of Nigeria Nsukka.

Jamal, A. Mohamed, N. \& Ali, A. (2014). The impact of financial risks on the firms' performance. European Journal of Business and Management, 6(5), 210-233.

Kanu, C., \& Isu, I. (2016). Security Challenge, Bank Fraud and Deposit Money Bank Performance in Ngeria: An Evaluation. Journal of Business and Management, 5(2), 1-21

Kanu, S. I., \& Okorafor, E. O. (2013). The nature, extent and economic impact of fraud on bank deposits in Nigeria. Interdisciplinary Journal of Contemporary Research in Business, 4(9), 253-265.

Kariuki, P., \& Peddy, P. (2017), Operationalizing an effective mentoring and evaluation system for local government: Consideration for the best practice. African Evaluation Journal, 5(2), 1-16.

Makokha, P. S., Mukanzi, C., \& Maniagi, M. (2016). Influence of Financial risk on financial performance of deposit taking savings and credit co-operatives in Kakamega County. International Journal of Management and Commerce Innovations, 4(2), 509-518.

Muriithi, J. G., \& Muigai, R. G. (2017). Quantitative analysis of Financial risk and profitability of Kenyan Deposit Money Banks using Cost Income Ratio. Journal of Economics and Finance, 8(3), 76-83. 
International Journal of Business and Management Review

Vol.8, No.4, pp.78-100, July 2020

Published by ECRTD-UK

Print ISSN: 2052-6393(Print), Online ISSN: 2052-6407(Online)

Nataraja, N. S., Nagaraja, R. C., \& Ganesh, L. (2018). Financial performance of Private Deposit Money banks in India: Multiple regression analysis. Academy of Accounting and Financial Studies Journal, 22(2), 1-12

Nwankwo, O. (2013). Implications of fraud on Deposit Money banks' performance in Nigeria. International Journal of Business and Management, 8(15), 144-150. doi:10.5539/ijbm.v8n15p144

Olalere, O. E, Aminul, I., Yusoff, W. S., \& Shamsuddin, Z. (2018). An investigation into Financial risk in Deposit Money Banks: Empirical evidence from Nigeria. International Journal of Accounting, Finance and Business, 3(12), 49 - 62.

Olalere, O. E. \& Wan, W. O. (2013). The empirical effects of credit risk on profitability of Deposit Money banks: evidence from Nigeria. International Journal of Science and Research, 5(8), $1645-1650$

Osadahun, S. B. (2014). Financial risk management in the Nigerian banking Sector. Glasgow Caledonian. Caledonian Business School. Working Papers, 25(2).

Oyerogba, E. O., Ogungbade, O., \& Esiemogie, I. D. (2016). The relationship between the risk management practices and financial performance of the Nigerian listed banks. Accounting and Management Information Systems, 15(3), 565-587.

Pakhchanyan, S. (2016). Financial risk Management in Financial Institutions: A Literature Review. International Journal of Financial Studies Review, 8(5), 56-67.

Pinto, P., Hawaldar, I. T., Rahiman, H. U., Rajesha, T. M., \& Sarea, A. (2017). An evaluation of financial performance of Deposit Money banks. International Journal of Applied Business and Economic Research, 15(22), 605-618

Shrivastava, A., Kumar, K., \& Kumar, N. (2018). Business Distress Prediction Using Bayesian Logistic Model for Indian Firms. Risks, 6(1), 113-128.

Uchenna, C., \& Agbo, J. C. O. (2013). Impact of fraud and fraudulent practices on the performance of banks in Nigeria. British Journal of Arts and Social Sciences, 15(1), 12-28.

Ugwu, E. I. (2012). An appraisal of the impact of recapitalization of banking 